Volume 9. No. 2, February 2021

International Journal of Emerging Trends in Engineering Research

Available Online at http://www.warse.org/IJETER/static/pdf/file/ijeter10922021.pdf

https://doi.org/10.30534/ijeter/2021/10922021

\title{
PERFORMANCE ANALYSIS OF FUZZY LOGIC CONTROLLED HYBRID ACTIVE DC FILTER (HADF) FOR 12-PULSE HVDC CONVERTER
}

\author{
KIRAN YADDANAPUDI ${ }^{1 *}$, PANNALA KRISHNA MURTHY ${ }^{2}$ \\ $1^{*}$ Research Scholar, Department of Electrical \& Electronics Engineering, \\ Jawaharlal Nehru Technological University Hyderabad, Hyderabad, Email: kiran045@ gmail.com \\ ${ }^{2}$ Professor, Department of Electrical \& Electronics Engineering, \\ Khammam Institute of Technology and Sciences, Khammam, Email:krishnamurthy.pannala@gmail.com
}

\begin{abstract}
Transmission of power through High Voltage Alternating Current (HVAC) Transmission lines results in power losses in the transmission line, higher the length of transmission line higher the losses, furthermore cost of transmission line also increases with length. In order to maintain the voltage within the limits, reactive power also need to be transmitted over the same line which again increases the power losses. In order to overcome the above problems, High Voltage Direct Current (HVDC) is preferred to transmit the power when the distance of transmission is above $500 \mathrm{kM}$, which requires only one conductor for Monopolar Link and ground acts as return conductor. The converters used for conversion of power from ac to dc produce harmonics, which can be handled with the filters. In the proposed work a 12-pulse HVDC converter with Hybrid Active DC Filter (HADF) consisting of 100 MVAR Shunt Passive Filter and Shunt Active DC Power Filter controlled by fuzzy logic is designed and simulated in MATLAB/Simulink, Shunt Active DC Power Filter handled the higher order harmonics and compensated the remaining reactive power in addition to passive filters.
\end{abstract}

KEY WORDS: High Voltage DC Transmission, Passive Filters, Shunt Active DC Power Filter, Hybrid Active DC Filter, Fuzzy Logic Controller.

\section{INTRODUCTION}

Electrical Power when transmitted through High Voltage Alternating Current (HVAC) Transmission lines to the load, some amount of power is wasted in terms of losses which occur in the transmission line due to its parameters like resistance, inductance \& capacitance also skin effect, corona loss will also add to these losses. Furthermore to maintain the voltage within the specified limits, reactive power needs to be transmitted through these lines which also add to these power losses. To overcome above drawbacks the alternative solution is High Voltage Direct Current transmission. Transmission of Electrical Power through HVDC is economical when the length of transmission is above 500kM. HVDC has many advantages over HVAC such as low power losses, thinner conductor, small transmission towers, asynchronous interconnection of two grids with different electrical parameters, underground and under water power transmission etc.,[1]

On the other side HVDC transmission also possess a drawback such as generation of harmonics by converters, which can be reduced by additional filters installed at converter stations both at sending and receiving end. These filters can be either passive filters, active filters or both.

\section{TWELVE PULSE RECTIFIER}

In the proposed work a Twelve Pulse HVDC Rectifier with Hybrid Active DC Filter (HADF) consisting of 
KIRAN YADDANAPUDI et al., International Journal of Emerging Trends in Engineering Research, 9(2), February 2021, 70 - 74

shunt passive filters and shunt active dc power filter controlled by fuzzy logic is designed in MATLAB/Simulink as shown in Figure 1.

\subsection{Shunt Passive Filters}

The shunt passive filters such as, a Capacitor Bank, C Type High Pass 3rd Harmonic, Double Tuned 11th \& 13th Harmonic, High Pass 24th Harmonic Passive filters were designed for handling the dominant $11^{\text {th }}, 13^{\text {th }} \& 24^{\text {th }}$ harmonics with total reactive power of 100 MVAR as shown in Figure 2. The following equations were used for designing the passive filters,

Single Tuned Filter [2]:

$$
X_{c}=\frac{k V^{2}}{Q_{c}}
$$

$w \square$ ere $, X_{c}:$ Capacitive Reactance, $k V$ :Voltage in $k V$, $Q_{c}:$ Reactive Power

$$
\begin{aligned}
& X_{c}=\frac{1}{2 \pi f C_{1}} \\
& X_{L}=\frac{X_{C}}{\square n} \\
& X_{L}=2 \pi f L \\
& X_{n}=\sqrt{X_{L} X_{C}} \\
& R_{n}=\frac{X_{n}}{Q}
\end{aligned}
$$

C-Type High Pass $3^{\text {rd }}$ Harmonic Filter [3]:

$$
C=\frac{\left(\square^{2}-1\right) Q}{w V^{2}}
$$

$w \square$ ere $\square:$ Harmonic Order, Q: Reactive Power.

$w=2 \pi f, V:$ Voltage

$$
\begin{aligned}
L & =\frac{V^{2}}{\left(\square^{2}-1\right) Q w} \\
R & =Q_{f} w_{\square} L
\end{aligned}
$$

Double Tuned High Pass Filter $\left(11^{\text {th }} \& 13^{\text {th }}\right.$ Harmonics) [4]:

Let $C_{a}, L_{a}$ be the Capacitance \& Inductance of $11^{\text {th }}$ order harmonic Filter

Let $C_{b}, L_{b}$ be the Capacitance \& Inductance of $13^{\text {th }}$ order harmonic Filter

$$
\begin{aligned}
& C_{1}=C_{a}+C_{b} \\
& L_{1}=\frac{1}{C_{a} W_{a}^{2}+C_{b} W_{b}^{2}} \\
& W_{s}=\frac{1}{\sqrt{L_{1} C_{1}}} \\
& W_{p}=\frac{W_{a} W_{b}}{W_{s}} \\
& L_{2}=\frac{\left(1-\frac{W_{a}^{2}}{W_{s}^{2}}\right)\left(1-\frac{W_{a}^{2}}{W_{p}^{2}}\right)}{C_{1} W_{a}^{2}} \\
& C_{2}=\frac{1}{L_{2} W_{p}^{2}}
\end{aligned}
$$

\begin{tabular}{|c|c|c|c|c|}
\hline \multicolumn{5}{|c|}{$\begin{array}{l}\text { Shunt Passive Filters (100 MVAR) for Twelve Pulse Rectifier 475kV, } \\
50 \mathrm{~Hz}\end{array}$} \\
\hline & $\begin{array}{l}\text { Capacitor } \\
\text { Bank } \\
\text { (25MVAR) }\end{array}$ & $\begin{array}{l}\text { C Type High } \\
\text { Pass } 3^{\text {rd }} \\
\text { Harmonic } \\
\text { ( 25MVAR) }\end{array}$ & $\begin{array}{c}\text { Double Tuned } 11^{\text {th }} \\
\& 13^{\text {th }} \text { Harmonic } \\
(25 \mathrm{MVAR})\end{array}$ & $\begin{array}{l}\text { High Pass } 24^{\text {th }} \\
\text { Harmonic } \\
\text { (25MVAR) }\end{array}$ \\
\hline $\mathrm{C}$ & $352.8 \mathrm{nF}$ & $2.823 \mu \mathrm{F}$ & - & $352.8 \mathrm{nF}$ \\
\hline $\mathrm{C} 1$ & - & $352.8 \mathrm{nF}$ & $705.6 \mathrm{nF}$ & - \\
\hline $\mathrm{L}$ & - & $3.592 \mathrm{H}$ & - & $49.89 \mathrm{mH}$ \\
\hline $\mathrm{R}$ & - & 6767Ohms & 380Ohms & $53.70 \mathrm{Ohms}$ \\
\hline $\mathrm{C} 2$ & - & - & $25.69 \mu \mathrm{F}$ & - \\
\hline L1 & - & - & $99.13 \mathrm{mH}$ & - \\
\hline L2 & - & - & $2.80 \mathrm{mH}$ & - \\
\hline
\end{tabular}

The design parameters of shunt passive filters were shown in Table.1.

\subsection{Shunt Active DC Power Filter}

A shunt active dc power filter capable of mitigating high order harmonics and providing a reactive power of 330 MVAR is designed in MATLAB/Simulink with reference dc voltage of $900 \mathrm{kV}$ and dc link capacitance of $47 \mu \mathrm{F}$ is controlled by fuzzy logic assisted PI controller as shown in Figure 3.. Fuzzy Logic Controller for $\mathrm{kp}$, ki and their membership functions are shown in Figure 4-Figure 7. Fuzzy Rule Base for kp, ki were shown in Table 3 \& Table 4. The design parameters of the proposed system are shown in Table.2.

Table 1 Design Parameters of 100 MVAR Passive Filters

Table 2 Design Parameters of Proposed System

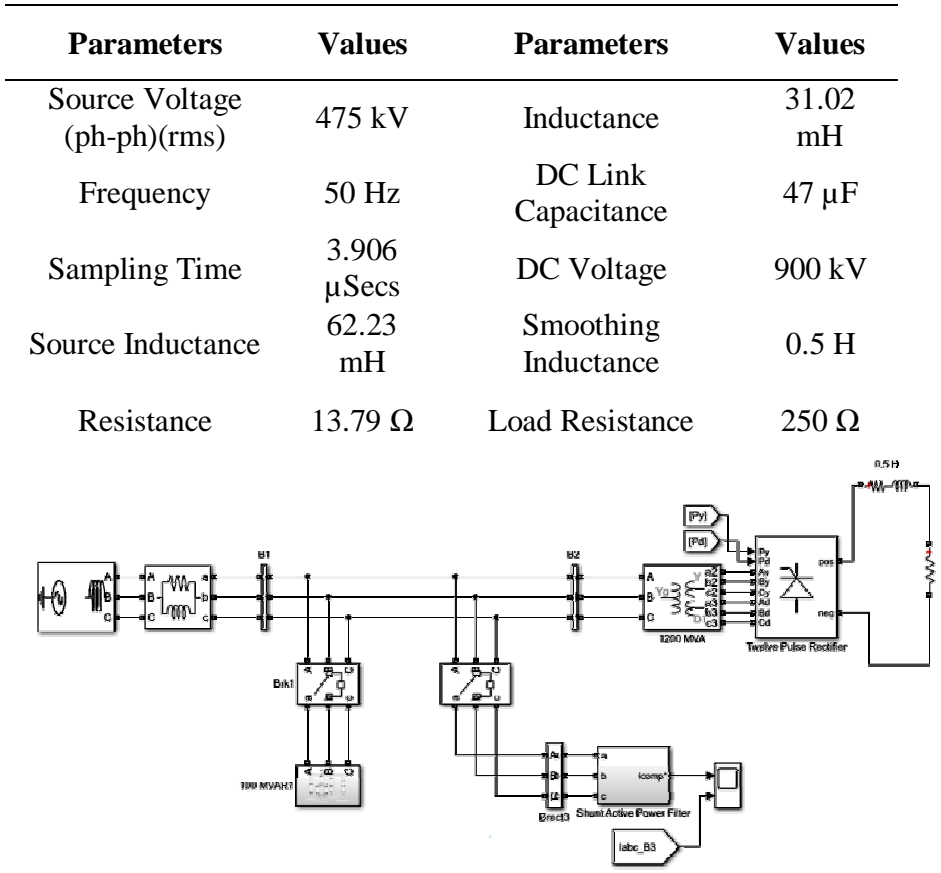

Figure 1 MATLAB/Simulink Model of Proposed 12-Pulse HVDC Converter with Fuzzy Logic Controlled HADF 
KIRAN YADDANAPUDI et al., International Journal of Emerging Trends in Engineering Research, 9(2), February 2021, 70 - 74

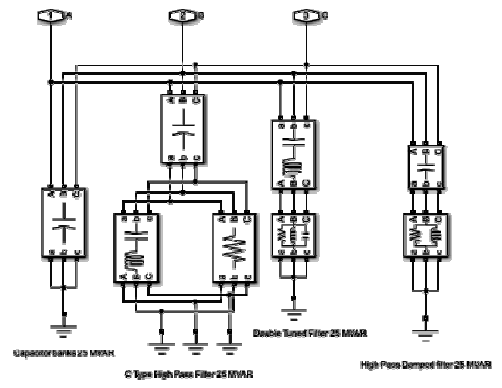

Figure 2 MATLAB/Simulink Model of 100 MVAR Passive Filters

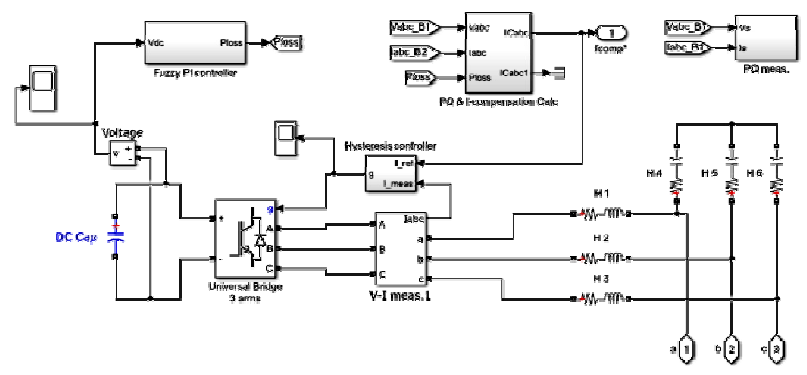

Figure 3 MATLAB/Simulink Model of Shunt Active DC Power Filter (SAPF) controlled by Fuzzy Logic

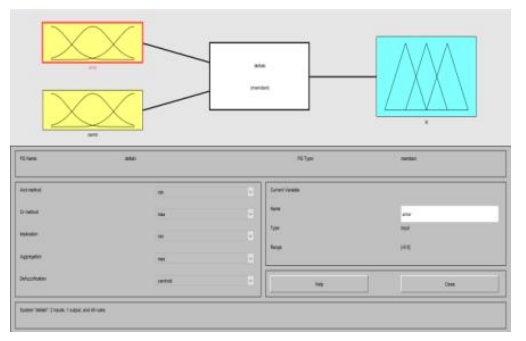

Figure 4 MATLAB/Simulink Fuzzy Logic Designer for kp

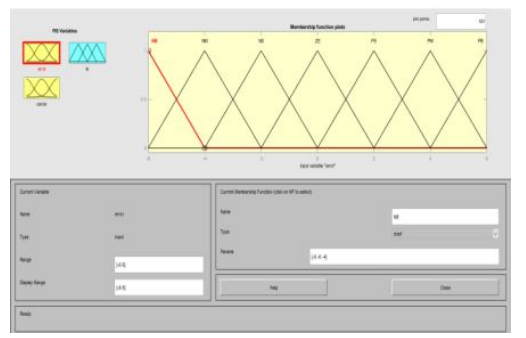

Figure 5 MATLAB/Simulink Fuzzy Logic Membership Function of $\mathrm{kp}$

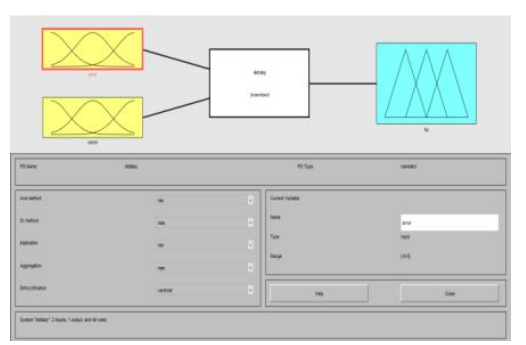

Figure 6 MATLAB/Simulink Fuzzy Logic Designer for ki

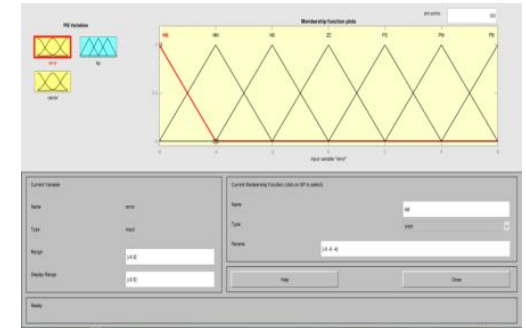

Figure 7 MATLAB/Simulink Fuzzy Logic Membership Function of ki

Table 3 MATLAB/Simulink Fuzzy Rule Base for kp

\begin{tabular}{|c|c|c|c|c|c|c|c|}
\hline \multirow{2}{*}{$\begin{array}{c}\text { Error } \\
(\mathbf{e})\end{array}$} & \multicolumn{7}{|c|}{ Change of Error (ce) for kp } \\
\cline { 2 - 8 } & NH & NM & NL & ZE & PL & PM & PH \\
\hline NH & PH & NH & PH & NH & PH & NH & PH \\
\hline NM & PH & NM & PH & NM & PH & NM & PH \\
\hline NL & PM & NL & PM & NL & PM & NL & PM \\
\hline ZE & PM & ZE & PM & ZE & PM & ZE & PM \\
\hline PL & PL & PL & PL & PL & PL & PL & PL \\
\hline PM & ZE & PM & ZE & PM & ZE & PM & ZE \\
\hline PH & ZE & PH & ZE & PH & ZE & PH & ZE \\
\hline
\end{tabular}

Table 4 MATLAB/Simulink Fuzzy Rule Base for ki

\begin{tabular}{|c|c|c|c|c|c|c|c|}
\hline \multirow{2}{*}{$\begin{array}{c}\text { Error } \\
(\mathbf{e})\end{array}$} & \multicolumn{7}{|c|}{ Change of Error (ce) for ki } \\
\cline { 2 - 8 } & NH & NM & NL & ZE & PL & PM & PH \\
\hline NH & ZE & ZE & NH & NM & NM & ZE & ZE \\
\hline NM & ZE & ZE & NM & NM & NL & ZE & ZE \\
\hline NL & ZE & ZE & NL & NL & ZE & ZE & ZE \\
\hline ZE & ZE & ZE & NL & NM & PL & ZE & ZE \\
\hline PL & ZE & ZE & ZE & PL & PL & ZE & ZE \\
\hline PM & ZE & ZE & NL & PM & PH & ZE & ZE \\
\hline PH & ZE & ZE & NL & PM & PH & ZE & ZE \\
\hline
\end{tabular}

\section{SIMULATION}

Fuzzy Logic Controlled Hybrid Active DC Filter (HADF) for 12-Pulse HVDC Converter is simulated in MATLAB/Simulink environment and the waveforms of Source Voltage and Current were analyzed without and with filters. The Total Harmonic Distortion of the Source Voltage and Current without and with filters were also analyzed.

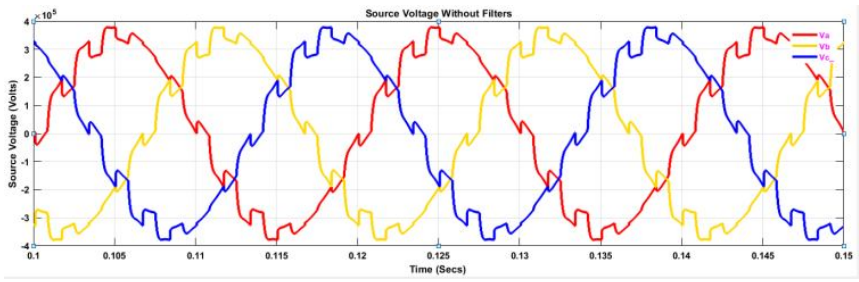

Figure 8 Source Voltage without Filters 


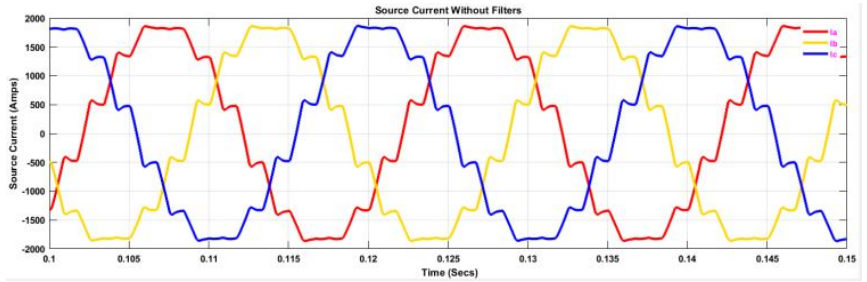

Figure 9 Source Current without Filters

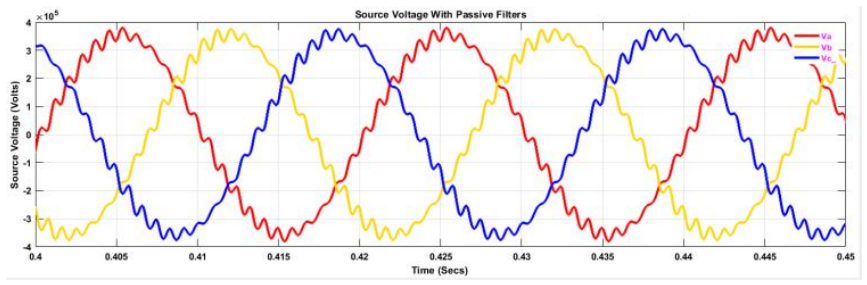

Figure 10 Source Voltage with Shunt Passive Filters

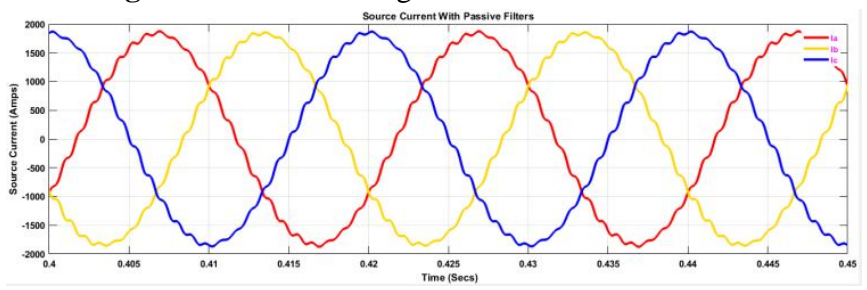

Figure 11 Source Current with Shunt Passive Filters

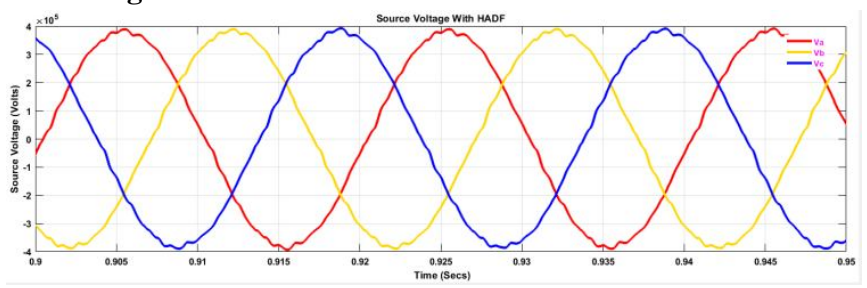

Figure 12 Source Voltage with HADF

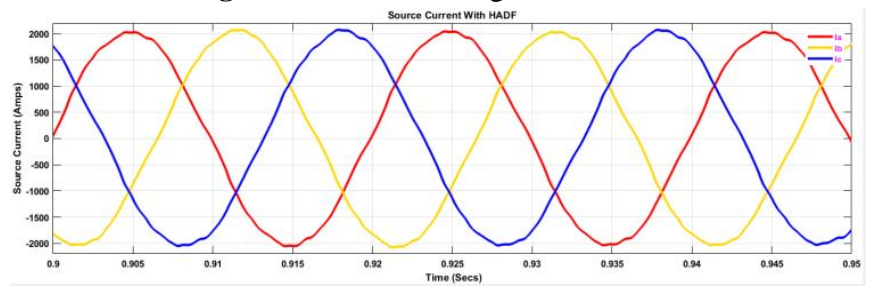

Figure 13 Source Current with HADF

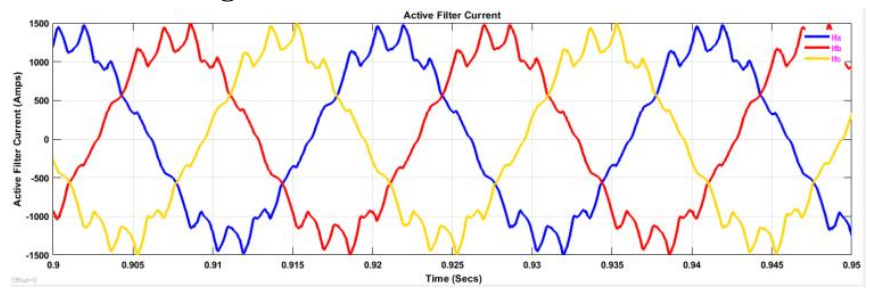

Figure 14 Active Filter Current

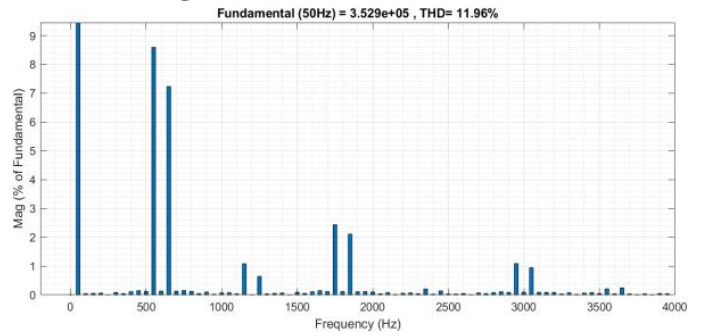

Figure 15 THD of Source Voltage without Filters

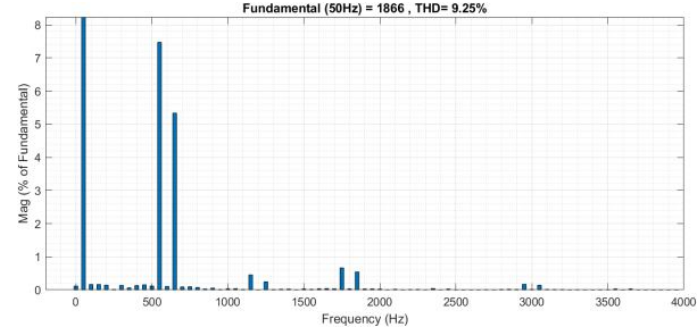

Figure 16 THD of Source Current without Filters

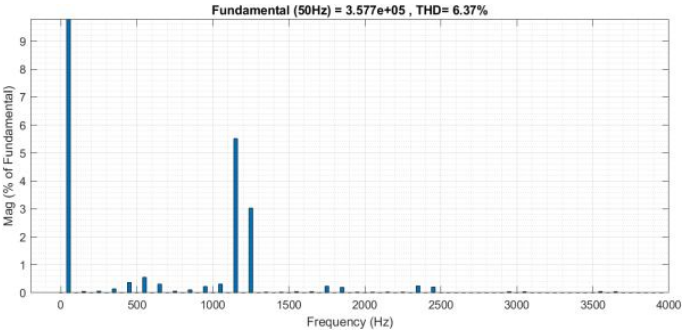

Figure 17 THD of Source Voltage with Passive Filters

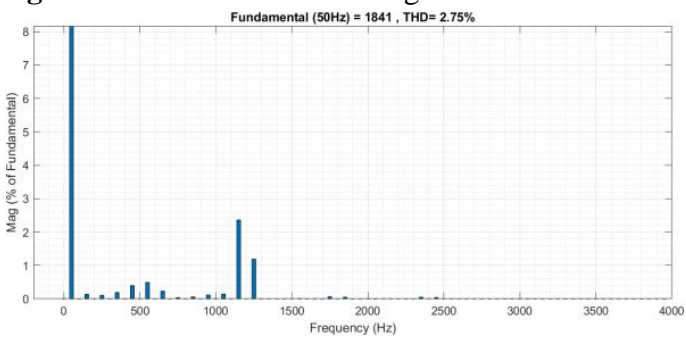

Figure 18 THD of Source Current with Passive Filters

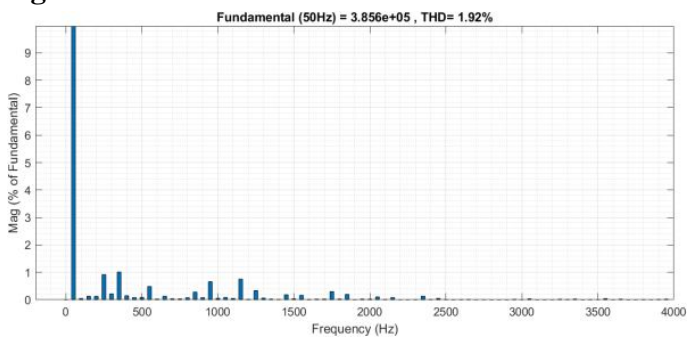

Figure 19 THD of Source Voltage with HADF

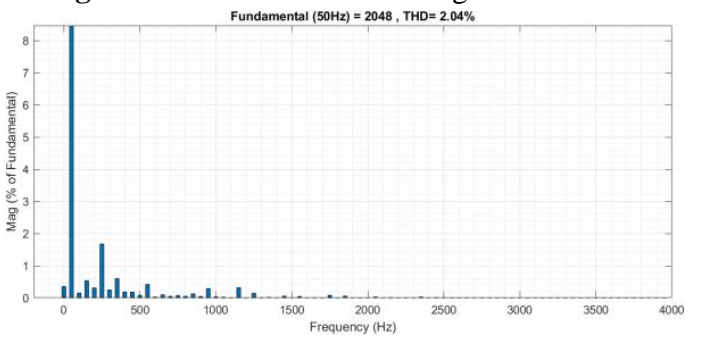

Figure 20 THD of Source Current with HADF

Table 5 Total Harmonic Distortion of Source Voltage and Current

\begin{tabular}{cccc}
\hline \multicolumn{4}{c}{$\begin{array}{c}\text { Total Harmonic Distortion of Source Voltage and Source } \\
\text { Current of Twelve Pulse Rectifier (in \%) }\end{array}$} \\
\hline Signal & $\begin{array}{c}\text { Without } \\
\text { Filters }\end{array}$ & $\begin{array}{c}\text { With 100 } \\
\text { MVAR } \\
\text { Filters }\end{array}$ & With HADF \\
\hline $\mathrm{Va}$ & 11.93 & 6.37 & 1.92 \\
$\mathrm{Vb}$ & 11.93 & 6.37 & 1.67 \\
$\mathrm{Vc}$ & 11.93 & 6.37 & 1.85
\end{tabular}


KIRAN YADDANAPUDI et al., International Journal of Emerging Trends in Engineering Research, 9(2), February 2021, 70 - 74

$\begin{array}{llll}\text { Ia } & 9.21 & 2.75 & 2.37 \\ \text { Ib } & 9.21 & 2.75 & 2.04 \\ \text { Ic } & 9.21 & 2.75 & 2.08\end{array}$

Table 6 DC Voltage and Current

\begin{tabular}{cccc}
\hline \multicolumn{4}{c}{ DC Voltage and Current } \\
\hline Signal & $\begin{array}{c}\text { Without } \\
\text { Filters }\end{array}$ & $\begin{array}{c}\text { With 100 } \\
\text { MVAR } \\
\text { Filters }\end{array}$ & $\begin{array}{c}\text { With } \\
\text { HADF }\end{array}$ \\
\hline $\begin{array}{c}\text { Voltage } \\
(\mathrm{kV})\end{array}$ & 453.7 & 469.1 & 504.1 \\
$\begin{array}{c}\text { current } \\
(\mathrm{kA})\end{array}$ & 1.815 & 1.877 & 2.016
\end{tabular}

\section{RESULTS AND DISCUSSIONS}

Initially Source Voltage and Source Current were distorted and non sinusoidal as they contain harmonics as no filter is connected as shown in Figure 8 and Figure 9. The THD of Source Voltage and Source Current without filters is $11.96 \%$ and $9.25 \%$ as shown in Figure 15 and Figure 16.

When 100 MVAR Shunt Passive Filters were connected the lower order harmonics in the Source Voltage and Source Current were eliminated but they contain some higher order harmonics so they are deviating from sinusoidal nature as shown in Figure 10 and Figure 11. The THD of Source Voltage and Source Current with Passive Filters is $6.37 \%$ and $2.75 \%$ as shown in the Figure 17 and Figure 18.

After Connecting Shunt Active DC Power Filter controlled by Fuzzy Logic, the higher order harmonics in the Source Voltage and Source Current were also eliminated now the Source Voltage and Source Current are nearer to sinusoidal waveform as shown in the Figure 12 and Figure 13. The Filter Current is shown in the Figure 14. The THD of Source Voltage and Source Current is $1.92 \%$ and $2.04 \%$ as shown in the Figure 19 and Figure 20.

The THD of Source Voltage and Source Current without and with filters is shown in Table 5.

The DC Voltage and DC Current at the output of 12-Pulse Rectifier were also boosted up by connecting Passive and Shunt Active DC Power Filter as shown in Table 6.

\section{CONCLUSIONS}

Converters play a vital role in the power industry for conversion of power from ac to dc and vice versa, in spite of the fact that these require filters for eliminating harmonic injected by them, these are used widely. Filters can be passive or active. In the proposed work both passive and active filters are connected to the 12-Pulse Rectifier, it is observed that the Shunt Passive filters provide fixed reactive power compensation of 100 MVAR eliminating lower order harmonics but the Shunt Active DC Power Filter provides a variable reactive compensation depending upon the changes in the load and is able eliminate higher order harmonics and also increases the dc voltage and current at the output of 12Pulse Rectifier. It can be concluded that the size of the passive filters can be reduced by selecting a suitable active filter for reactive power compensation of the system.

\section{REFERENCES}

[1] https://www.electricaltechnology.org/2020/06/advantage s-of-hvdc-over-hvac-power-transmission.html

[2] D. M. Soomro, M. M. Almelian," Optimal Design of A Single Tuned Passive Filter To Mitigate Harmonics In Power Frequency", ARPN Journal of Engineering And Applied Sciences, Vol. 10, No. 19, October 2015, ISSN 1819-6608 pp.9009-9014.

http://www.arpnjournals.org/jeas/research_papers/rp_20 15/jeas_1015_2828.pdf

[3] I A Shah, R K Ali, and N Khan," Design of A C-Type Passive Filter For Reducing Harmonic Distortion and Reactive Power Compensation", International Journal of Software \& Hardware Research In Engineering, Volume 4 Issue 12 December, 2016, issn-2347-4890,pp.38-47. https://ijournals.in/wpcontent/uploads/2017/07/6.41203-Imran.compressed.pdf

[4] He Yi-Hong, Su Heng, "A New Method of Designing Double-Tuned Filter", Proceedings of The 2nd International Conference On Computer Science And Electronics Engineering (ICCSEE 2013), pp.206-209. https://www.atlantis-press.com/proceedings/iccsee$13 / 4485$ 